\title{
Testosterone modulation of ethanol effects on the $\mu$-opioid receptor kinetics in castrated rats
}

\author{
RAFAAT KHALIL and JESSICA HUMANN \\ Department of Biology, Florida A\&M University College of Science and Technology, \\ Tallahassee, FL 32307, USA
}

Received December 27, 2018; Accepted June 5, 2019

DOI: $10.3892 /$ br.2019.1230

\begin{abstract}
The present investigation was conducted to evaluate the effects of testosterone on ethanol-induced alterations of $\mu$-opioid receptor binding kinetics in specific brain regions of castrated rats. Male Sprague Dawley rats (100-124 g) adapted to a 12-h light/dark cycle were used. Animals were castrated under pentobarbital anesthesia. After a recovery period of 14 days, ethanol [3 g/ $\mathrm{kg}$ as $22.5 \%$ solution in saline via intraperitoneal injection (i.p.)], testosterone [2.5 $\mathrm{mg}$ in $0.2 \mathrm{ml}$ of olive oil via subcutaneous injection (s.c.) in the dorsal neck region] or the combination of ethanol and testosterone were administered to rats at 9:00 a.m. The control group was injected i.p. with $2 \mathrm{ml}$ saline and s.c. with $0.2 \mathrm{ml}$ olive oil for 7 days. Animals were sacrificed by decapitation at $2 \mathrm{~h}$ after the final injection. The brains were immediately removed, and the cortex, hippocampus, hypothalamus and midbrain were dissected. In an attempt to elucidate the mechanism involved in the hormonal modulation of the effects of ethanol and testosterone on the endogenous opioid system, the binding kinetics of the $\mu$-opioid receptors were determined. The results obtained in the present study assisted in identifying the regulatory role of testosterone on ethanol-induced changes on $\mu$-opioid receptor binding kinetics.
\end{abstract}

\section{Introduction}

Alcohol has been demonstrated to have a complex effect on the central nervous system (1). These effects involve neurobehavioral changes that affect emotional state, sensory function and cognitive performance (2). The specific regions of the brain that are selectively vulnerable to the acute effects of alcohol are the cerebral cortex, the limbic system and the cerebellum $(2,3)$. Collectively, these regions of the brain control a number of functional activities, and are involved in cognitive

Correspondence to: Dr Rafaat Khalil, Department of Biology, Florida A\&M University College of Science and Technology, 1601 Martin Luther King Jr Blvd, Tallahassee, FL 32307, USA

E-mail: rafaat.khalil@famu.edu

Key words: testosterone, ethanol, opioid receptor kinetics processing, motor control, the expression of emotions and mood state $(4,5)$. In individuals with alcoholism, dysregulation of neurotransmission in the prefrontal cortex is associated with learning deficits, $\mu$-opioid receptor deficits, and the subsequent loss of control of drinking behavior (6).

The endogenous opioid system has a crucial role in alcoholism. It is considered to contribute significantly to alcohol-induced reinforcement learning and eventually alcoholism (7). Investigations into the effect of alcohol on the opioid system extended further to the level of the $\mu$ - and $\kappa$-opioid receptors, where decreased consumption of alcohol has been reported in $\mu$ - and $\kappa$-opioid receptor knockout mice $(8,9)$. In current practice, the $\mu$-opioid receptor antagonists naltrexone and nalmefene are used in the treatment of alcoholism (10-13).

Studies investigating the pathophysiology of alcoholism at cellular and molecular levels indicate that alcohol affects hormone and neurotransmitter-activated signal transduction, leading to changes in gene expression; these changes in the brain may be a likely cause of a number of the acute and chronic neurological events in alcoholism (14). In addition, microarray and RNA-sequence studies have indicated that the expression of numerous genes involved in receptor function and receptor-mediated G-protein signaling are altered in the frontal cortex of individuals with alcoholism. These changes may contribute to the progression from occasional alcohol consumption to alcohol dependence (15). Alcohol also has a selective effect on the $\mu$-opioid receptor in the hippocampus, altering spatial learning, whereas the effect of alcohol on the cortical area $\mu$-opioid receptors may cause behavioral sensitization and cognitive function disorders $(2,16,17)$.

Alcohol is one of the most commonly abused substances by opioid users (18). Biochemical and pharmacological evidence has revealed that the reinforcing properties of alcohol may partially be due to the alcohol-induced activation of the endogenous opioid system $(19,20)$. The $\mu$-opioid receptors have a high receptor density and mRNA expression in the thalamus, basal ganglia, amygdala, cortex and hippocampus, with intermediate densities in the hypothalamus $(21,22)$. Selective and non-selective $\mu$-opioid receptor antagonists have been demonstrated to suppress voluntary alcohol consumption in rodents (23). In addition, alcohol self-administration was increased in $\beta$-endorphin ( $\beta$-END) deficient-mice (24) whereas $\mu$-opioid receptor knockout mice did not consume alcohol ad libitum (8). 
At the hormonal level, high testosterone levels have been associated with increased alcohol consumption and an increased risk of developing alcoholism $(25,26)$. However, chronic alcoholism has been demonstrated to induce hypogonadism and signs of feminization in males (27). Steroid-induced reinforcement has been considered to be associated with the opioid system. The opioid system may affect the steroid levels in the periphery and in the brain (28). Similarly, steroids may also affect the levels of endogenous opioids and opioid receptors $(29,30)$.

In male rats treated with the anabolic androgen steroid nandrolone, elevated $\beta$-END levels and decreased dynorphin levels in the ventral tagmental area and nucleus accombens region were observed (30,31). Nandrolone-treated rats also exhibited increased alcohol consumption (32). The aim of the present study was to investigate whether testosterone may serve a regulatory role in $\mu$-opioid receptor alteration in the brain by ethanol.

\section{Materials and methods}

Animal sample collection. A total of 32 6-week-old male Sprague-Dawley rats (100-124 g), purchased from Harlan Inc., were used in the present study. The animal protocol was approved by the Animal Care and Use Committee of Florida A\&M University (Florida, USA). Animals were housed in groups of 4 animals per cage and kept under a 12-h light/dark cycle (fluorescent light, 30-40 lux) at a constant temperature $\left(23^{\circ} \mathrm{C}\right)$ and humidity (50-60\%). Water and food (Purina Lab Chow, Purina) were provided ad libitum. All animals were castrated bilaterally under pentobarbital anesthesia $[50 \mathrm{mg} / \mathrm{kg}$ intraperitoneal (i.p.)]. A sharp incision was made in the scrotum opening of the tunica vaginalis, exteriorizing the testis. The spermatic cord and vas were doubly ligated and transected as a single unit. Animals were monitored for a recovery period of 14 days.

Drug treatment. Animals were randomly assigned to four groups. The first group $(\mathrm{n}=7)$ received $2 \mathrm{ml} 0.9 \%$ saline i.p. (control), the second group $(\mathrm{n}=9)$ received ethanol $[3 \mathrm{~g} / \mathrm{kg}$ as $22.5 \% \mathrm{w} / \mathrm{v}$ solution in saline, i.p.], the third group $(n=7)$ received testosterone propionate [Sigma-Aldrich; Merck $\mathrm{KGaA} ; 2.5 \mathrm{mg} / \mathrm{rat}$ in $0.2 \mathrm{ml}$ olive oil; subcutaneous injection (s.c.) in the dorsal neck region], and the fourth group $(n=9)$ received a combination of ethanol and testosterone. The difference in the number of the animal groups was to compensate for any risk of loss that may result from ethanol injection. These drugs were administered at 9:00 a.m. Control and ethanol-treated groups also received $0.2 \mathrm{ml}$ olive oil s.c. in the dorsal neck regions for 7 days.

At the end of the 7th day the rats were sacrificed by decapitation, and the brain tissue was removed onto an ice-cold surface, and then flash frozen in liquid nitrogen and kept at $-70^{\circ} \mathrm{C}$. The frozen brains were dissected into cortex, hypothalamus, hippocampus and midbrain regions and maintained at $-70^{\circ} \mathrm{C}$ until assay (within 1 week). These brain regions were selected due to their involvement in controlling learning, behavior, $\mu$-opioid receptors, endocrine function and motor activity.

Membrane preparation for opioid receptor binding. Brain regions were pooled (3-4 rat brain region per pool) and homogenized by hand using a Wheaton Teflon-on-glass tissue homogenizer (Duran Wheaton Kimble Life Sciences) in 50 volumes of ice-cold (50 mM Tris- $\mathrm{HCl})$ buffer $(\mathrm{pH} 7.4)$ and centrifuged at $20,000 \mathrm{x}$ g for $20 \mathrm{~min}$ at $4^{\circ} \mathrm{C}$ using a Beckman L8-80M ultracentrifuge (Beckman Coulter, Inc.). The pellet was washed twice by resuspension and centrifuged as aforementioned. The final pellet obtained was dispersed in an ice-cold buffer to give a final tissue concentration of $20 \mathrm{mg} / \mathrm{ml}$.

$\mu$-opioid receptor binding assay. A modification of the method described by Schoffelmeer et al (33) was used for radio-receptor assay of $\mu$-opioid receptors. A total of two sets of borosilicate glass tubes (12x75 mm duplicates) were used for either total or non-specific binding. In the total binding assay, each tube contained $100 \mu \mathrm{l}{ }^{3} \mathrm{H}$-Tys-D-Ala-Gly-N-Methyl-Phe-Gly-ol $\left[{ }^{3} \mathrm{H}-\mathrm{DAMGO}\right.$; NEN Life Science Products (PerkinElmer, Inc.); $50.5 \mathrm{Ci} / \mathrm{mmol}$; 0.14-9 $\mathrm{nM}$ final concentration] and $100 \mu \mathrm{l}$ captopril in assay buffer $(300 \mu \mathrm{M}$ final concentration) to protect against degradation of the labeled ligand. Incubation was initiated by adding $300 \mu \mathrm{l}$ tissue homogenate. For non-specific binding, defined as 'any binding site different than the receptor of interest example filters, and tubes' while specific binding, defined as 'binding of cold ligand to receptor of interest', $300 \mu \mathrm{l}$ tissue homogenate was transferred to tubes containing $100 \mu \mathrm{l}{ }^{3} \mathrm{H}$-DAMGO and $100 \mu \mathrm{l}$ unlabeled ligand DAMGO (1 $\mu \mathrm{M}$ final concentration) and captopril $(300 \mu \mathrm{M})$ in buffer. Assay tubes were incubated at $37^{\circ} \mathrm{C}$ for $30 \mathrm{~min}$ in a shaking water bath. Incubation was terminated by filtration under decreased pressure through Brandel GF/B glass fiber filters, presoaked in $0.1 \%$ polyethyleneimine, using Brandel cell Harvester, M-12R (Brandel) followed by 2 washes with $5 \mathrm{ml}$ ice-cold assay buffer. Membrane filters containing bound radioactivity were then transferred to ScintiVerse ${ }^{\mathrm{TM}}$ scintillation cocktail (Thermo Fisher Scientific, Inc.) and allowed to stand at room temperature for at least $5 \mathrm{~h}$, to dissolve all radioligands and to attain maximum count.

Radioactivity was counted at $45 \%$ efficiency using LKB Rack-beta counter model 1219 (LKB instruments). Specific binding was defined as the difference in ${ }^{3} \mathrm{H}$-DAMGO binding observed in the absence and presence of $1 \mu \mathrm{M}$ unlabeled DAMGO. The dissociation equilibrium constant $\left(\mathrm{K}_{\mathrm{d}}\right)$ and total receptor concentration $\left(\mathrm{B}_{\max }\right)$ values were calculated using the nonlinear regression analyses using Ligand analysis program (Equilibrium Binding Data Analysis and LIGAND Elsevier-BioSOFT; version 2.3.22).

Statistical analysis. Data was analyzed by one-way analysis of variance followed by Bonferroni's post-hoc test using GraphPad Prism version 5.00 for Windows (GraphPad Software, Inc.). $\mathrm{P}<0.05$ was considered to indicate a statistically significant difference. Data are presented as the mean \pm standard error of the mean. Binding assays were performed in triplicate for each sample, and the experiments repeated twice.

\section{Results}

DAMGO is a radioligand labeled drug that is associated with $\mu$-opioid receptor (34). Measuring the rate and extent of binding provides information of the number and affinity of binding sites, and while physiological or biochemical measurements of 
tissue responses to drugs may prove the existence of receptors only ligand binding studies are able to determine the actual receptor concentration.

Effects of ethanol, testosterone and combination treatment on $B_{\text {max }}$ in brain areas. Fig. 1 demonstrates that the administration of ethanol alone resulted in a significant $20 \%$ increase in $\mathrm{B}_{\max }$ compared with the control $(\mathrm{P}<0.05)$ in the cortex, when testosterone administered concomitantly with ethanol in the same area returned the number of receptors back to normal level. Administration of testosterone alone resulted in a significant decrease in $\mathrm{B}_{\max }$ compared with the control $(\mathrm{P}<0.05)$ in the hippocampus. Administration of ethanol and testosterone together resulted in a significant decrease in the $\mathrm{B}_{\max }$ of the $\mu$-opioid receptor in the hypothalamus, hippocampus and midbrain compared with the control $(\mathrm{P}<0.05)$. The results also indicated that the testosterone reversal of ethanol induced an increase in $\mathrm{B}_{\max }$ in the cortex. No significance between groups were observed.

Effects of ethanol, testosterone and combination treatment on $K_{d}$ in brain areas. Fig. 2 indicates that neither ethanol administration nor testosterone resulted in any significant change in the $\mathrm{K}_{\mathrm{d}}$ of $\mu$-opioid receptors in the hypothalamus, while concurrent administration of ethanol and testosterone resulted in a significant increase in the $\mathrm{K}_{\mathrm{d}}$ of these receptors in the hypothalamus compared with the control $(\mathrm{P}<0.05)$. No significant change in the $\mu$-opioid receptors $\mathrm{K}_{\mathrm{d}}$ was observed in the hippocampus following the administration of ethanol, while the administration of testosterone alone, and concomitant administration of ethanol and testosterone resulted in a significant increase in the $\mathrm{K}_{\mathrm{d}}$ of these receptors in this brain region compared with the control. $(\mathrm{P}<0.05)$. Neither ethanol administration nor testosterone resulted in a significant change in the $\mu$-opioid receptors $\mathrm{K}_{\mathrm{d}}$ in the midbrain, while joint administration of ethanol and testosterone resulted in a significant increase of $\mathrm{K}_{\mathrm{d}}$ in the midbrain compared with the control $(\mathrm{P}<0.05)$.

Neither administration of ethanol alone nor with testosterone resulted in a significant increase in the $\mathrm{K}_{\mathrm{d}}$ of these receptors in the cortex, while administration of testosterone alone resulted in a significant increase in the $\mathrm{K}_{\mathrm{d}}$ of these receptors in the cortex compared with the control $(\mathrm{P}<0.05)$.

\section{Discussion}

Previous studies have indicated that alcohol and male sex hormones affect the brain endogenous opioid receptors $(20,30)$. Opioid peptides, particularly $\beta$-END and enkephalins, have been suggested to mediate the reinforcing properties of alcohol $(7,35)$. Testosterone modulation of the $\mu$-opioid receptor has been well documented, where the involvement of androgen receptor (AR) in pain and analgesic processing has been explained by the distribution of AR in brain regions known for pain modulation (36-38). Medications targeting the $\mu$-opioid receptors are considered the most effective and widely used drugs for treatment of severe pain through ligand binding to the $\mu$-opioid receptor. Although pain response was not assessed in the present study, and it would be useful to examine the different factors involved. It was demonstrated previously that the spinal cord cells of male rats expressed increased levels of $\mu$-opioid receptors in comparison with females, and that the depletion of sex hormones produced opposite effects, reflecting an increased tolerance to pain in males compared with females (39). An increase in numbers of $\mu$-opioid receptors reflects an increase in endogenous ligand levels in males, producing tolerance to pain. When testosterone levels are depleted, ligand levels and receptor numbers are decreased, eliminating the tolerance to pain induced by testosterone. In the cortex, ethanol induced an increase in $\mathrm{B}_{\max }$; when testosterone was administered with alcohol, the receptor numbers were reversed and returned to normal levels. Testosterone has been demonstrated to have analgesic effects in several pre-clinical and clinical (40) pain models (41-46). The analgesic effect of testosterone is promoted, at least in part, by $\mu$-opioid receptor regulation $(41,47)$. Testosterone modulated the expression of $\mu$-opioid receptors in the midbrain periaqueductal gray (38). Inflammatory cytokines levels induced by $\mu$-opioid receptor upregulation were inhibited in the trigeminal sensory ganglia (TG) of gonadectomized (GDX) male rats. In addition, testosterone replacement in GDX male rats restored the expression and function of testosterone-dependent modulation of $\mu$-opioid receptors in TG, suggesting that AR may also regulate $\mu$-opioid receptor gene expression (48).

The $\mu$-opioid receptor kinetics results obtained in the present study support the aforementioned hypothesis concerning the effects of ethanol-based testosterone modulation on $\mu$-opioid receptors. Testosterone replacement significantly decreased the $\mu$-opioid receptor density over the gonadectomized control in the hippocampus. Accordingly, studies have revealed that the hippocampus responds to external agents, including hormones, stressors and pain (49). However, previous studies have indicated that gonadectomy alone or gonadectomy followed by chronic testosterone replacement using silastic capsules did not change the $\mu$-opioid receptor characteristics in the entire brain of adult male rats (50-54). These previous studies investigated testosterone effects in the entire brain, and any discrepancies may be due to the routes of administration used (54). However, different studies have suggested that gonadectomy increases the number of $\left[{ }^{3} \mathrm{H}\right]$ naltrexone or $\left[{ }^{3} \mathrm{H}\right]$ naloxone binding sites by a factor of 2 in the brains of male rats, and 7 days of subcutaneous testosterone $(2.5 \mathrm{mg} / \mathrm{kg})$ administration reverses this effect by decreasing their number to control normal levels $(55,56)$.

In the present study, administration of testosterone significantly decreased the $\mu$-opioid $\mathrm{B}_{\max }$ in the hippocampus, and concomitantly increased $\mathrm{K}_{\mathrm{d}}$ of these receptors in the same brain region. These observations suggest that testosterone may decrease the affinity of $\mu$-agonists binding to their receptors, and that these changes may be due to a conformational change in the receptors, decreased numbers of the receptors and alteration of the gene expression level. A similar trend was observed in the cortex, where testosterone significantly increased the $\mathrm{K}_{\mathrm{d}}$ of $\mu$-opioid receptors. Ethanol did not alter the $\mu$-binding affinity, $\mathrm{K}_{\mathrm{d}}$, in any of the areas examined, which was additionally supported by the observation that individuals abstaining from alcohol exhibit increased $\mu$-opioid receptor binding $(57,58)$. These data 


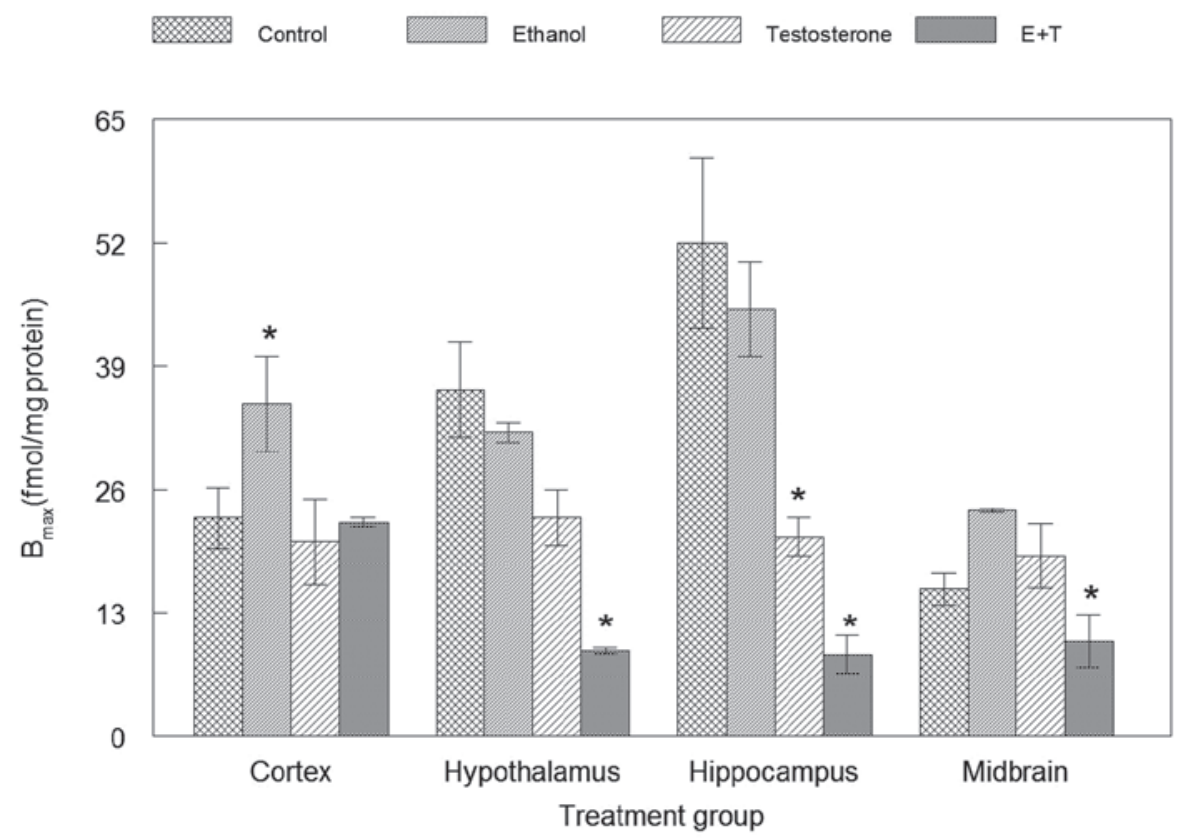

Figure 1. Effects of ethanol, testosterone and combination treatment vs castrated control on Bmax in brain areas. Data are expressed as the mean \pm standard error of the mean. " $\mathrm{P}<0.05$ Bmax represented by maximum amount of drug (fmol/mg protein) that is able to bind specifically to the receptors in a membrane preparation; $\mathrm{E}+\mathrm{T}$, combination of ethanol and testosterone. Bmax, total number of $\mu$-opioid receptors.

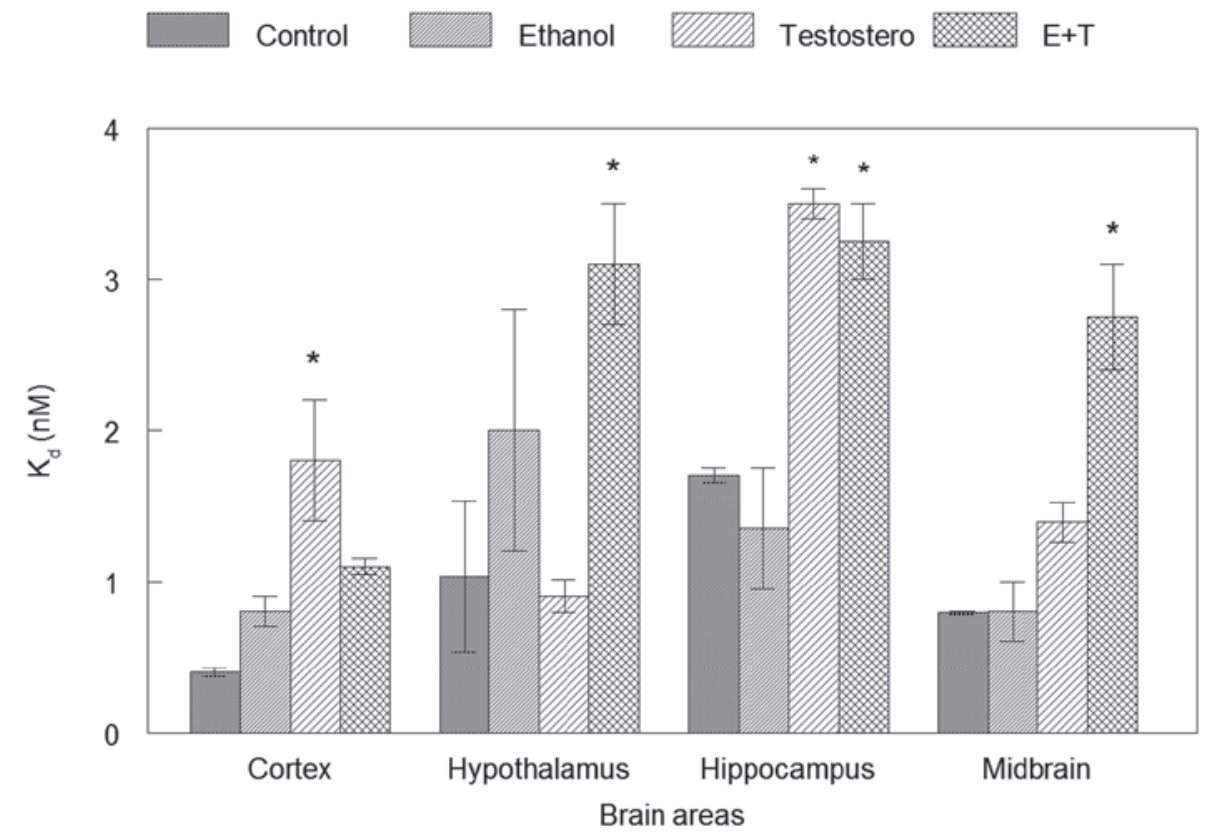

Figure 2. Effects of ethanol, testosterone and combination treatment on $\mathrm{Kd}$ in brain areas vs castrated control. Data are expressed as the mean \pm standard error of the mean. ${ }^{*} \mathrm{P}<0.05 . \mathrm{K}_{\mathrm{d}}$, the equilibrium dissociation constant $(\mathrm{nM})$.

provide evidence of involvement of the opioid system in testosterone-induced $\mu$-opioid receptor effects, investigated previously (39). In addition, localization of AR expression and $\mu$-opioid expression on the same neuron provides mechanisms by which testosterone may exert regulation of the $\mu$-opioid receptors, through activation of the transcriptional machinery of the $\mu$-opioid receptor gene in primary afferent nociceptors, where it binds directly to the region of the $\mu$-opioid receptor gene promoter (41). In the present study, concurrent administration of testosterone and ethanol was accompanied by a significant decrease of $B_{\max }$ and an increase of $K_{d}$, which indicated a decreased affinity of the $\mu$-opioid receptors in hypothalamus and midbrain regions. The periaqueductal gray is the gray matter located around the cerebral aqueduct within the tegmentum of the midbrain, where there is a high concentration of $\mu$-opioid receptors. The ventral tegmental area is a group of dopaminergic neurons located in the midbrain. Evidence has indicated that an interaction exists between opioid peptides and midbrain dopaminergic neurons (59); in addition, brain 
circuits that are activated by opioids are in the mesolimbic (midbrain) reward system. The principle underlying mechanisms of drug addiction (such as alcohol, amphetamine and opioids) appear to be the capacity of these substances to enhance dopamine release in the mesolimbic pathway (60). This molecular mechanism is considered to serve an important role in the reinforcement of drug-seeking and consumption behavior (61). The present study focused on testosterone modulation of ethanol alteration on $\mu$-opioid receptor kinetics. Additional studies are required to include dopaminergic interactions. Previous studies have confirmed that $\mu$-opioid receptors exhibit testosterone-dependent modulation of their expression levels in the periaqueductal gray (38). Apostolinas et al (62) suggested that testosterone replacement for the duration of 1 week was sufficient to induce numbers of neurons containing high concentrations of AR, including the amygdala or hypothalamus, within the range of normal male mice. Animal studies in both rodents and primates have demonstrated that androgen deprivation led to a decrease of $40 \%$ of synaptic density in the hippocampus, and that testosterone replacement in male animals normalized synaptic density, indicating that the testosterone replacement was effective in reaching its receptor in the brain and normalizing the brain structures damaged by gonadectomy (63). These data suggest that androgens have a marked effect on the maintenance of the nervous system through the AR (64). In the present study, in samples from the cortex, ethanol increased the $\mathrm{B}_{\max }$ compared with the control, and testosterone replacement abolished the increase of $\mathrm{B}_{\max }$ when administered in combination with ethanol in the same area. This indicated that the increase in $\mathrm{B}_{\max }$ is due to the ethanol effect and not to gonadectomy, as co-administration of ethanol and testosterone in the same area was not significantly different compared with that of the control.

$\mu$-opioid receptors have been identified in the striatum, cortex, hippocampus, amygdala, raphe nuclei and thalamic nuclei, amongst other regions (65-67). The anterior cingulate cortex (ACC) is also a key site of opioid action in humans and rodents $(68,69)$. It has been suggested that opioid receptor binding in the ACC is highly associated with cravings during early abstinence in alcohol-dependent subjects (70).

Although previous studies have suggested that alcohol does not alter ligand binding to $\mu$-opioid receptors $(71,72)$, other studies have indicated that alcohol has been consistently demonstrated to differentially alter $\mu$-opioid receptor binding in brain tissue and neuroblastoma cell lines, depending on the study conditions $(73,74)$. The results from the present study suggested that alcohol altered the binding kinetics of $\mu$-opioid receptors and that the administration of testosterone modulated the effects of alcohol on $\mu$-opioid receptor binding kinetics in castrated rats. These data suggest an association between $\mu$-opioid receptors, alcohol and testosterone. Although the results do not confirm a causative association, changes in receptor binding kinetics and the ligand-receptor complex, rather than the receptors themselves, determines the ultimate physiological cellular response. In vitro studies do not always reflect physiological or pharmacological response that will occur in vivo. These results may, in part, explain the beneficial effects of male gonadal hormone in patients with alcoholism. However, the present study contained certain limitations: Firstly, larger sample sizes may provide sufficient statistical power to resolve the additional effects of ethanol and testosterone; secondly, alcohol administered once daily via i.p. injection does not reflect the actions of dietary alcohol administered by gavage; finally, the present study lacked a group of intact non-castrated animals to provide a direct comparison to an identical condition within intact animals.

\section{Acknowledgements}

The authors would like to thank Dr Magdi Soliman, Florida A\&M University College of Pharmacy for providing laboratory facilities.

\section{Funding}

The present study was supported by the National Institutes of Health (grant no. RR03020).

\section{Availability of data and materials}

The analyzed data sets generated during the study are available from the corresponding author on reasonable request.

\section{Authors' contributions}

RK designed and performed experiments, and wrote the manuscript. JH was responsible for critical revision of the manuscript, including data interpretation and intellectual content.

\section{Ethics approval and consent to participate}

The animal protocol was approved by the Animal Care and Use Committee of Florida A\&M University.

\section{Patient consent for publication}

Not applicable.

\section{Competing interests}

The authors declare that they have no competing interests.

\section{References}

1. Mitchell MC: Alcohol-induced impairment of central nervous system function: Behavioral skills involved in driving. J Stud Alcohol Suppl 10: 109-116, 1985.

2. Fillmore MT: Drug abuse as a problem of impaired control: Current approaches and findings. Behav Cogn Neurosci Rev 2: 179-197, 2003.

3. Lee H, Roh S and Kim DJ: Alcohol-induced blackout. Int J Environ Res Public Health 6: 2783-2792, 2009.

4. Marieb EN and Hoehn K: Human anatomy \& physiology. 10th edition. Pearson Education, 2010

5. Bardo MT: Neuropharmacological mechanisms of drug reward: Beyond dopamine in the nucleus accumbens. Crit Rev Neurobiol 12: 37-67, 1998.

6. Moselhy HF, Georgiou $\mathrm{G}$ and Kahn A: Frontal lobe changes in alcoholism: A review of the literature. Alcohol Alcohol 36: 357-368, 2001. 
7. Vengeliene V, Bilbao A, Molander A and Spanagel R: Neuropharmacology of alcohol addiction. Br J Pharmacol 154: 299-315, 2008

8. Roberts AJ, McDonald JS, Heyser CJ, Kieffer BL, Matthes HW, Koob GF and Gold LH: mu-Opioid receptor knockout mice do not self-administer alcohol. J Pharmacol Exp Ther 293: 1002-1008, 2000.

9. Kovacs KM, Szakall I, O'brien D, Wang R, Vinod KY, Saito M, Simonin F, Kieffer BL and Vadasz C: Decreased oral self-administration of alcohol in kappa-opioid receptor knock-out mice. Alcohol Clin Exp Res 29: 730-738, 2005.

10. Kiefer F, Jiménez-Arriero MA, Klein O, Diehl A and Rubio G: CLINICAL STUDY: Cloninger's typology and treatment outcome in alcohol-dependent subjects during pharmacotherapy with naltrexone. Addict Biol 13: 124-129, 2008.

11. Rubio G, Ponce G, Rodriguez-Jiménez R, Jiménez-Arriero MA, Hoenicka $\mathrm{J}$ and Palomo T: Clinical predictors of response to naltrexone in alcoholic patients: Who benefits most from treatment with naltrexone? Alcohol Alcohol 40: 227-233, 2005.

12. Aubin HJ, Reimer J, Nutt DJ, Bladström A, Torup L, François C and Chick J: Clinical relevance of as-needed treatment with nalmefene in alcohol-dependent patients. Eur Addict Res 21: $160-168,2015$.

13. Gual A, He Y, Torup L, van den Brink W and Mann K; ESENSE 2 Study Group: A randomised, double-blind, placebo-controlled, efficacy study of nalmefene, as-needed use, in patients with alcohol dependence. Eur Neuropsychopharmacol 23: 1432-1442, 2013.

14. Diamond I and Gordon AS: Cellular and molecular neuroscience of alcoholism. Physiol Rev 77: 1-20, 1997.

15. Warden AS and Mayfield RD: Gene expression profiling in the human alcoholic brain. Neuropharmacology 122: 161-174, 2017.

16. Steketee JD: Neurotransmitter systems of the medial prefrontal cortex: Potential role in sensitization to psychostimulants. Brain Res Brain Res Rev 41: 203-228, 2003.

17. Silvers JM, Tokunaga S, Berry RB, White AM and Matthews DB: Impairments in spatial learning and memory: Ethanol, allopregnanolone, and the hippocampus. Brain Res Brain Res Rev 43 275-284, 2003

18. Oliver P, Forrest R and Keen J: Does the combined use of heroin or methadone and other substances increase the risk of overdose. Res Brief, 2007.

19. Froehlich JC: Genetic factors in alcohol self-administration. J Clin Psychiatry 56 (Suppl 7): 15-23, 1995.

20. Ulm RR, Volpicelli JR and Volpicelli LA: Opiates and alcohol self-administration in animals. J Clin Psychiatry 56 (Suppl 7): S5-S14, 1995.

21. Pfeiffer A, Pasi A, Mehraein P and Herz A: Opiate receptor binding sites in human brain. Brain Res 248: 87-96, 1982.

22. Frost JJ, Douglass KH, Mayberg HS, Dannals RF, Links JM, Wilson AA, Ravert HT, Crozier WC and Wagner HN Jr: Multicompartmental analysis of [11C]-carfentanil binding to opiate receptors in humans measured by positron emission tomography. J Cereb Blood Flow Metab 9: 398-409, 1989.

23. Stromberg MF, Casale M, Volpicelli L, Volpicelli JR and O'Brien CP: A comparison of the effects of the opioid antagonists naltrexone, naltrindole, and beta-funaltrexamine on ethanol consumption in the rat. Alcohol 15: 281-289, 1998.

24. Grisel JE, Mogil JS, Grahame NJ, Rubinstein M, Belknap JK, Crabbe JC and Low MJ: Ethanol oral self-administration is increased in mutant mice with decreased beta-endorphin expression. Brain Res 835: 62-67, 1999.

25. Eriksson CJ, Kaprio J, Pulkkinen L and Rose RJ: Testosterone and alcohol use among adolescent male twins: Testing between-family associations in within-family comparisons. Behav Genet 35: 359-368, 2005.

26. La Grange L, Jones TD, Erb L and Reyes E: Alcohol consumption: Biochemical and personality correlates in a college student population. Addict Behav 20: 93-103, 1995.

27. Sinclair M, Grossmann M, Gow PJ and Angus PW: Testosterone in men with advanced liver disease: Abnormalities and implications. J Gastroenterol Hepatol 30: 244-251, 2015

28. Katz N and Mazer NA: The impact of opioids on the endocrine system. Clin J Pain 25: 170-175, 2009.

29. Hammer RP Jr and Bridges RS: Preoptic area opioids and opiate receptors increase during pregnancy and decrease during lactation. Brain Res 420: 48-56, 1987.
30. Pluchino N, Ninni F, Casarosa E, Giannini A, Merlini S, Cubeddu A, Luisi M, Cela V and Genazzani AR: Sex differences in brain and plasma beta-endorphin content following testosterone, dihydrotestosterone and estradiol administration to gonadectomized rats. Neuroendocrinology 89: 411-423, 2009.

31. Johansson P, Ray A, Zhou Q, Huang W, Karlsson K and Nyberg F: Anabolic androgenic steroids increase beta-endorphin levels in the ventral tegmental area in the male rat brain. Neurosci Res 27 $185-189,1997$.

32. Johansson P, Lindqvist A, Nyberg F and Fahlke C: Anabolic androgenic steroids affects alcohol intake, defensive behaviors and brain opioid peptides in the rat. Pharmacol Biochem Behav 67: 271-279, 2000

33. Schoffelmeer AN, Warden G, Hogenboom F and Mulder AH: Beta-endorphin: A highly selective endogenous opioid agonist for presynaptic mu opioid receptors. J Pharmacol Exp Ther 258: 237-242, 1991.

34. Gillan M and Kosterlitz H: Spectrum of the mu, delta- and kappa-binding sites in homogenates of rat brain. Br J Pharmacol 77: 461-469, 1982

35. Herz A: Endogenous opioid systems and alcohol addiction. Psychopharmacology (Berl) 129: 99-111, 1997.

36. Murphy AZ, Shupnik MA and Hoffman GE: Androgen and estrogen (alpha) receptor distribution in the periaqueductal gray of the male rat. Horm Behav 36: 98-108, 1999.

37. Hamson DK, Jones BA and Watson NV: Distribution of androgen receptor immunoreactivity in the brainstem of male rats. Neuroscience 127: 797-803, 2004.

38. Loyd DR and Murphy AZ: Androgen and estrogen (alpha) receptor localization on periaqueductal gray neurons projecting to the rostral ventromedial medulla in the male and female rat. J Chem Neuroanat 36: 216-226, 2008.

39. Kren MC, Haller VL and Welch SP: The role of gonadal hormones on opioid receptor protein density in arthritic rats. Eur J Pharmacol 578: 177-184, 2008.

40. Schlegel PN: Clomiphene citrate for the treatment of low testosterone associated with chronic opioid pain medication administration. ClinicalTrials.gov Identifier: NCT01880086. https://clinicaltrials.gov/ct2/show/study/NCT01880086. Accessed July 17,2018

41. Lee KS, Zhang Y, Asgar J, Auh QS, Chung MK and Ro JY: Androgen receptor transcriptionally regulates $\mu$-opioid receptor expression in rat trigeminal ganglia. Neuroscience 331: 52-61, 2016.

42. Rosen S, Ham B and Mogil JS: Sex differences in neuroimmunity and pain. J Neurosci Res 95: 500-508, 2017.

43. Aloisi AM: Gonadal hormones and sex differences in pain reactivity. Clin J Pain 19: 168-174, 2003.

44. Lee KS, Asgar J, Zhang Y, Chung MK and Ro JY: The role of androgen receptor in transcriptional modulation of cannabinoid receptor type 1 gene in rat trigeminal ganglia. Neuroscience 254: 395-403, 2013.

45. Tyagi V, Scordo M, Yoon RS, Liporace FA and Greene LW: Revisiting the role of testosterone: Are we missing something? Rev Urol 19: 16-24, 2017.

46. Sobas EM, Reinoso R, Cuadrado-Asensio R, Fernández I, Maldonado MJ and Pastor JC: Reliability of potential pain biomarkers in the saliva of healthy subjects: Inter-individual differences and intersession variability. PLoS One 11: e0166976, 2016.

47. Macedo CG, Fanton LE, Fischer L and Tambeli CH: Coactivation of $\mu$-and $\kappa$-opioid receptors may mediate the protective effect of testosterone on the development of temporomandibular joint nociception in male rats. J Oral Facial Pain Headache 30: 61-67, 2016.

48. Zhang X, Zhang Y, Asgar J, Niu KY, Lee J, Lee KS, Schneider M and Ro JY: Sex differences in $\mu$-opioid receptor expression in trigeminal ganglia under a myositis condition in rats. Eur J Pain 18: 151-161, 2014

49. McEwen BS and Milner TA: Hippocampal formation: Shedding light on the influence of sex and stress on the brain. Brain Res Rev 55: 343-355, 2007

50. Cicero TJ, Newman KS and Meyer ER: Testosterone does not influence opiate binding sites in the male rat brain. Life Sci 33: 1231-1239, 1983

51. Diez JA and Roberts DL: Evidence contradicting the notion that gonadal hormones regulate brain opiate receptors. Biochem Biophys Res Commun 108: 1313-1319, 1982.

52. Olasmaa M, Limonta P, Maggi R, Dondi D, Martini L and Piva F: Further evidence that gonadal steroids do not modulate brain opiate receptors in male rats. Endocrinol Jpn 34: 521-529, 1987. 
53. Wilkinson M, Herdon $\mathrm{H}$ and Wilson CA: Gonadal steroid modification of adrenergic and opiate receptor binding in the central nervous system. ScienceDirect: 253-263, 1981.

54. Slamberová R, Rimanóczy A, Schindler CJ and Vathy I: Cortical and striatal mu-opioid receptors are altered by gonadal hormone treatment but not by prenatal morphine exposure in adult male and female rats. Brain Res Bull 62: 47-53, 2003.

55. Hahn EF and Fishman J: Changes in rat brain opiate receptor content upon castration and testosterone replacement. Biochem Biophys Res Commun 90: 819-823, 1979.

56. Hahn EF and Fishman J: Castration affects male rat brain opiate receptor content. Neuroendocrinology 41: 60-63, 1985.

57. Heinz A, Reimold M, Wrase J,Hermann D, Croissant B, Mundle G, Dohmen BM, Braus DF, Schumann G, Machulla HJ, et al: Correlation of stable elevations in striatal mu-opioid receptor availability in detoxified alcoholic patients with alcohol craving: A positron emission tomography study using carbon 11-labeled carfentanil. Arch Gen Psychiatry 62: 57-64, 2005.

58. Weerts EM, Wand GS, Kuwabara H, Munro CA, Dannals RF, Hilton J, Frost JJ and McCaul ME: Positron emission tomography imaging of mu- and delta-opioid receptor binding in alcohol-dependent and healthy control subjects. Alcohol Clin Exp Res 35: 2162-2173, 2011.

59. Steidl S, Wasserman DI, Blaha CD and Yeomans JS Opioid-induced rewards, locomotion, and dopamine activation: A proposed model for control by mesopontine and rostromedial tegmental neurons. Neurosci Biobehav Rev 83: 72-82, 2017

60. Di Chiara G, Bassareo V, Fenu S, De Luca MA, Spina L, Cadoni C, Acquas E, Carboni E, Valentini V and Lecca D: Dopamine and drug addiction: The nucleus accumbens shell connection. Neuropharmacology 47 (Suppl 1): S227-S241, 2004.

61. Sulzer D: How addictive drugs disrupt presynaptic dopamine neurotransmission. Neuron 69: 628-649, 2011.

62. Apostolinas S, Rajendren G, Dobrjansky A and Gibson MJ: Androgen receptor immunoreactivity in specific neural regions in normal and hypogonadal male mice: Effect of androgens. Brain Res 817: 19-24, 1999.

63. Leranth C, Petnehazy O and MacLusky NJ: Gonadal hormones affect spine synaptic density in the CA1 hippocampal subfield of male rats. J Neurosci 23: 1588-1592, 2003.

64. Young WJ and Chang C: Ontogeny and autoregulation of androgen receptor mRNA expression in the nervous system. Endocrine 9: 79-88, 1998.
65. Mansour A, Khachaturian H, Lewis ME, Akil H and Watson SJ: Autoradiographic differentiation of mu, delta, and kappa opioid receptors in the rat forebrain and midbrain. J Neurosci 7 : 2445-2464, 1987

66. Mansour A, Fox CA, Burke S, Meng F, Thompson RC, Akil H and Watson SJ: Mu, delta, and kappa opioid receptor mRNA expression in the rat CNS: An in situ hybridization study. J Comp Neurol 350: 412-438, 1994

67. Tempel A and Zukin RS: Neuroanatomical patterns of the mu, delta, and kappa opioid receptors of rat brain as determined by quantitative in vitro autoradiography. Proc Natl Acad Sci USA 84: 4308-4312, 1987.

68. Vogt LJ, Sim-Selley LJ, Childers SR, Wiley RG and Vogt BA: Colocalization of mu-opioid receptors and activated G-proteins in rat cingulate cortex. J Pharmacol Exp Ther 299: 840-848, 2001.

69. Jones AK, Qi LY, Fujirawa T, Luthra SK, Ashburner J, Bloomfield $\mathrm{P}$, Cunningham VJ, Itoh $\mathrm{M}$, Fukuda $\mathrm{H}$ and Jones T: In vivo distribution of opioid receptors in man in relation to the cortical projections of the medial and lateral pain systems measured with positron emission tomography. Neurosci Lett 126 : 25-28, 1991.

70. Williams TM, Davies SJ, Taylor LG, Daglish MR, Hammers A, Brooks DJ, Nutt DJ and Lingford-Hughes A: Brain opioid receptor binding in early abstinence from alcohol dependence and relationship to craving: An [11C]diprenorphine PET study. Eur Neuropsychopharmacol 19: 740-748, 2009.

71. Hiller JM, Angel LM and Simon EJ: Multiple opiate receptors: Alcohol selectively inhibits binding to delta receptors. Science 214: 468-469, 1981

72. Pfeiffer A, Seizinger BR and Herz A: Chronic ethanol imbibition interferes with delta-, but not with mu-opiate receptors. Neuropharmacology 20: 1229-1232, 1981.

73. Hoffman PL, Urwyler S and Tabakoff B: Alterations in opiate receptor function after chronic ethanol exposure. J Pharmacol Exp Ther 222: 182-189, 1982

74. Tabakoff B, Urwyler S and Hoffman PL: Ethanol alters kinetic characteristics and function of striatal morphine receptors. J Neurochem 37: 518-521, 1981.

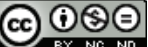

This work is licensed under a Creative Commons Attribution-NonCommercial-NoDerivatives 4.0 International (CC BY-NC-ND 4.0) License. 